\title{
The Price of Abuse: Intel and the European Commission Decision
}

Robert H. Lande

University of Baltimore School of Law, rlande@ubalt.edu

Follow this and additional works at: http://scholarworks.law.ubalt.edu/all_fac

Part of the Antitrust and Trade Regulation Commons, Computer Law Commons, and the Consumer Protection Law Commons

\section{Recommended Citation}

The Price of Abuse: Intel and the European Commission Decision, 5 GCP: The Online Magazine for Global Competition Policy, No. 2, June 2009

This Article is brought to you for free and open access by the Faculty Scholarship at ScholarWorks@University of Baltimore School of Law. It has been accepted for inclusion in All Faculty Scholarship by an authorized administrator of ScholarWorks@University of Baltimore School of Law. For more information, please contact snolan@ubalt.edu. 


\section{The Price of Abuse: Intel and the European Commission Decision}

Robert H. Lande University of Baltimore School of Law 


\title{
The Price of Abuse: Intel and the European Commission Decision
}

\author{
Robert H. Lande ${ }^{1}$
}

\section{INTRODUCTION}

\section{1}

he May 13, 2009 decision by the European Commission ("EC") holding that Intel violated Article 82 of the Treaty of Rome and should be fined a record amount and prohibited from engaging in certain conduct, set off a predictable four part chorus of denunciations:

1. Intel did nothing wrong and was just competing hard;

2. Intel's discounts were good for consumers;

3. The entire matter is just another example of Europeans protecting their own against a more efficient U. S. company; and

4. Even if Intel did engage in anticompetitive activity, the fine was much too large.

These assertions will be addressed in turn.

\section{WAS INTEL SIMPLY ENGAGING IN NORMAL COMPETITION ON THE MERITS?}

The European Commission rightfully condemned Intel for abusing its monopoly position in the marketplace. Specifically, the EC ruled that Intel:

- "[G]ave wholly or partially hidden rebates to computer manufacturers on condition that they bought all, or almost all, their x86 CPUs from Intel."

- “[M]ade payments to major retailer Media Saturn Holding from October 2002 to December 2007 on condition that it exclusively sold Intel-based PCs in all countries in which Media Saturn Holding is active."

- "II]nterfered directly in the relations between computer manufacturers and AMD. Intel awarded computer manufacturers payments-unrelated to any particular purchases from Intel-on condition that these computer manufacturers postponed or cancelled the launch of specific AMD-based products."

${ }^{1}$ Venable Professor of Law at the University of Baltimore School of Law, and a Director of the American Antitrust Institute. I would like to thank John Connor and Bert Foer for helpful suggestions, and Christine Carey for excellent research assistance. 
It's difficult to even conceive of legitimate business justifications for these practices. None of this constitutes competition on the merits. None of it constitutes competition on the basis of efficiency, price, quality, variety, or service. None of it is even close to the line between legality and illegality. Rather, hidden rebates to computer manufacturers on condition they buy all, or almost all, of their x86 CPUs from Intel, and direct payments to a major retailer on condition it stock only computers with Intel x86 CPUs, effectively prevented customers - and ultimately consumers - from choosing alternative products even if those were the products they most wanted. Moreover, Intel's payments to computer manufacturers to halt or delay the launch of specific products containing competitors x86 CPUs as well as to limit the sales channels available to these products slows down the pace of innovation, which harms consumers directly.

This conduct anticompetitively restricted innovation and limited choice in the x86 microprocessor market. By contrast, free competition would have accelerated the very kind of innovative advances that offer consumers more choice and lower prices. Unless one does not believe that a main function of free markets is to provide consumers with better choices and lower prices through competition on the merits, there is no escaping the conclusion that Intel's conduct was anticompetitive.

\section{WERE INTEL'S DISCOUNTS GOOD FOR CONSUMERS?}

Intel and its apologists argue that Intel was offering discounts to computer makers and retailers that eventually were passed to consumers in the form of lower prices. Regardless of their effects on a competitor, shouldn't we focus on the consumers who ultimately will purchase the chips, and applaud Intel's discounts?

We should indeed focus on consumers. But this does not mean that Intel's discounts were in the public interest.

First, Intel's payments and discounts were shams. Prices only decreased after they had been increased initially. The only purpose of the reductions was to hinder an equally efficient competitor. ${ }^{2}$ Here is a very simplified version of how some of the discounts worked.

Imagine that Acme Computer buys 10 chips a month from Intel at $\$ 8$ each. Suppose AMD wanted to sell chips to Acme, and offered to sell it 2 chips at $\$ 5$ each.

\footnotetext{
${ }^{2}$ A recent American Antitrust Institute Working Paper authored by Norman Hawker, AAI Senior Fellow and Professor at Western Michigan University's Haworth College of Business, notes dynamics unique to the x86 industry that make it particularly vulnerable to coercive and exclusionary pricing schemes:
}

"[g]iven the razor thin profit margins of OEMs, they can hardly refuse to take advantage of the inducements offered by Intel. Put another way, they cannot risk discriminatory price retaliation or other punitive business terms that would disadvantage them against more 'loyal' competitors. Payment not to use AMD chips directly excludes AMD from competing in the marketplace. While below cost pricing is controversial in American antitrust law, the controversy primarily concerns whether such pricing occurs in a particular instance, not its anticompetitive effect." 
These lower AMD prices certainly would be beneficial for competition and consumers.

Suppose, however, that when Acme turned to Intel for the remaining 8 chips it needed, Intel replied that its prices had increased to $\$ 10$ per chip, but that if Acme purchased all 10 chips from Intel, their price would still only be $\$ 8$ each. Acme would quickly calculate that $\$ 8 \times 10=\$ 10 \times 8$. In other words, under Intel's new pricing plan it would be giving away the last two chips for free. It would make no sense for Acme to purchase any chips from AMD for $\$ 5$ each, or even for $1 \$$ each. From Intel's perspective it still gets the same $\$ 80$ from Acme Computer. In addition, its carefully designed "discount" has excluded its would-be competitor. This highly stylized rendition of a part of Intel's conduct shows how sham discounts can block entry and put even equally efficient rivals out of business.

Second, Intel did not make discounts generally available or compete generally on the basis of lower prices, either of which might well have led to lower prices for consumers. Rather it made its strategic and discriminatory payments or sham "first dollar" discounts to computer makers for the purpose of inducing them to boycott Intel's only significant rival, AMD, and it paid retailers on the condition they not carry products containing its rival's chips. There is a crucial difference between competing on the basis of lower prices, and paying to have a rival excluded. If this had been a track meet, the EC referee would not have found that Intel had used steroids to enable itself to run faster, but instead had tripped its rival.

The Commission rightly concluded that this attempted exclusion was "bad news for competition and consumers." If Intel is permitted to succeed in its anticompetitive campaign, one of the world's most critical industries might soon be monopolized completely and for the foreseeable future. In the long term, Intel's only true rival, AMD, could be weakened so much that it no longer will be able to invest the immense amounts required to engage in the innovation and to build the production facilities required to produce the next generation of chips. Investors will be reluctant to support future investment in innovation by Intel's only competitor if they know that Intel will be permitted to artificially limit the return on AMD's investments.

Intel not only undermined competition on the merits at a time when AMD had created a better product that threatened Intel, but also threatened the future of innovation in this market. Without the spur of a rival, Intel's incentives to innovate could fall substantially, and a dynamic duopoly could turn into a lazy monopolist. Consumers in the United States should be thankful the Europeans have taken this law enforcement action, because without it in the long run they would pay more and have inferior products.

IV. WAS THE COMMISSION JUST PROTECTING A EUROPEAN COMPETITOR? 
An early Wall Street Journal Review \& Outlook editorial on this case was titled, "Intel in Euro-Land." The Journal summarized its view: "[t]he case against Intel is the latest in a series of EU assaults on successful U.S. technology." Predictably, the Journal was outraged by the European Commission's Statement of Objections against Intel. How dare they tell U. S. companies how to conduct business! As usual, the Journal viewed the Commission's action as another pathetic example of jealous European regulators punishing a U.S. company for beating European high technology companies on the merits! In this case the European Commission actually was acting to protect such European companies as....

All this would make a great story, if only it were true. Step back for a few minutes. Forget the technical details only a computer nerd truly can understand, the legal charges only an antitrust lawyer can fathom, and all of the immense complications. Consider the big picture of what is really going on in the Intel case.

First, there is no European company that competes with Intel in the affected market. Intel's only significant $x 86$ rival, AMD, is American. Although AMD certainly did supply information to the Commission, its information was verified several times, and it was only one of many sources of information that the Commission relied upon. This experienced enforcement organization, whose work has in recent years been carefully scrutinized by an often unsympathetic reviewing court, naturally realizes that it can be used by competitors for their own purposes and that the evidence and arguments it puts forward will have to meet a high level of rigor.

Further, while some PCs purchased in Europe are made there, most are imported from Asia. If the Commission really is acting to help corporations, it can only be these mostly-Asian computer makers or the United States-based AMD. How likely is protecting either of these the Commission's true motive? Maybe, just maybe, the Commission actually is trying to do what it said: protect "competition" and protect "consumers" from, among other things, paying monopoly prices, and suffering from diminished consumer choice. Is this really intuitively implausible?

The Europeans have every right to tell any corporation that desires to do business in Europe how to behave. Conversely, any foreign company that wishes to sell within the United States has to compete by our rules. Consider what happened, for example, to the international vitamins cartels, which were organized out of Switzerland. Every cartel member was a European or Japanese vitamin manufacturer. Together they raised the prices of most vitamins sold in the United States for much of the 1990s, by an average of more than 40 percent. After they were caught, one company-Hoffman-La Roche, a Swiss company - alone paid a $\$ 500$ million fine to the U. S. government. The cartel also was subjected to a swarm of private treble damage suits in U.S. courts by victimized U.S. consumers. Even though no other country in the world imposes treble 
damages on price fixers, these foreign cartelists were forced to pay more than $\$ 4$ billion to American consumers in these private lawsuits.

Was the United States simply exhibiting hatred of Swiss companies? Of course not. The cartel members sold vitamins in the Unites States, so it is only fair they were subjected to our laws against price fixing. Similarly, it is fair for any foreign company wishing to operate in Europe to obey European laws. If Intel does not want to obey European laws, it can choose to forgo selling into the lucrative European market.

Moreover, the EC's findings are substantially similar to those of the Korean Fair Trade Commission, whose meticulous and detailed opinion found many of the same abuses that the EC documented. The Korean decision expressly penalized Intel for forcing South Korean consumers to purchase computers at higher prices given that domestic PC makers were forced to buy Intel's costlier CPUs. The Korean decision gives the EU findings substantial additional credibility.

The Japanese Fair Trade Commission entered into a settlement with Intel concerning many of these issues. Intel's conduct is also under very active investigation by the U.S. Federal Trade Commission and the New York Attorney General's Office. Intel might yet prevail on appeal in the EC case. But observers should not assign illegitimate motives to the European or Korean lawsuit or findings. The Commission's ultimate goal is neither to attack an American company nor to protect European firms. Far from being protectionist, the EU's decision is part of a growing worldwide consensus. Just as the European enforcers were protecting European consumers, the Koreans were protecting Korean consumers, and the Japanese were protecting Japanese consumers; let's hope the American enforcers will protect American consumers.

\section{WAS THE FINE TOO LARGE?}

Even if Intel's conduct was anticompetitive, was the Commission's $\$ 1.45$ billion fine too large? It was, after all, the largest fine ever imposed against a single corporation for a competition law or antitrust offense in any EC or U.S. case.

To the contrary, the fine was much too low.

Intel's total corporate sales during the violation period were approximately $\$ 184$ billion, and its sales of the relevant products, X86 chips, were somewhat less than \$131 billion. ${ }^{3}$ Thus, if the fine is figured as a percentage of Intel's total sales, it is slightly less than 1 percent; figured as a percentage of X86 chip sales, it is slightly greater than 1 percent. Viewed either way, a fine of approximately 1 percent is unlikely to be enough to convince Intel to change its illegal conduct. The opposite is in fact much more likely: the

${ }^{3}$ The violation period was Oct. 2002 to Dec. 2007. The $\$ 131$ billion total is for their Microprocessor revenue, so it includes more than just X86 chip revenue. These figures were obtained from Intel 10K and10Q financial statements for the relevant period. 
implicit message of a 1 percent fine is for Intel to simply assume that its costs went up by 1 percent and that dealing with the Commission is just another cost of doing business.

An alternative way to view the fine is as a percentage of Intel's firm-wide operating profits during the conduct period. Intel earned approximately $\$ 45$ billion profit overall during the violation period, and its Microprocessor profits were roughly $\$ 56$ billion. ${ }^{4}$ Even the lower figure is more than 30 times the EC's $\$ 1.45$ billion fine. Ideally we would compare this fine to the percentage of Intel's $\$ 45$ billion profit that was attributable to its illegal conduct. However, since the Commission did not compute this figure we cannot perform this calculation. One highly imperfect but nevertheless suggestive benchmark can, however, be provided by an empirical study of average cartel markups. Over a substantial period, illegal cartels have averaged mean markups of 31-49 percent, and median markups of 22-25 percent. ${ }^{5}$ I know of no similar figures ever computed for monopolies or dominant firms. Nevertheless, even the lowest of these figures suggests that if monopolies raise prices on average as high as cartels, Intel might have been able to raise prices by some 22 percent of $\$ 131$ billion, or $\$ 29$ billion, due to its illegal conduct, and that a fine at least this large would have been appropriate.

This same study found that cartels were able to achieve peak price increases that were at the monopoly levels, which were roughly double the mark-ups just mentioned. Thus it is certainly possible that Intel might have been able to raise prices by as much as 40 percent of its sales revenues, or roughly $\$ 50$ billion, due to its illegal conduct. This is an additional reason to believe the EC's $\$ 1.45$ billion fine surely left Intel with an immense profit from its violation.

Not only should the fine have been much larger: it could have been much larger. The Commission's Guidelines state: "[ $t$ ]he ceiling of fines that can be imposed on companies is fixed by Article 23(2) of Council Regulation No 1/2003 (10 percent of the undertaking's total turnover in the preceding business year)." To calculate: Intel's sales last year were $\$ 38$ billion, therefore the fine could have been $\$ 3.8$ billion. In addition, the Commission's Guidelines suggest that "fines may be based on up to 30 percent of the company's annual sales to which the infringement relates, multiplied by the number of years of participation in the infringement." Since the Commission's press release said that 30 percent of Intel's sales were in Europe, 30 percent of $\$ 131$ billion is $\$ 39$ billion; 30 percent of $\$ 39$ billion would yield an $\$ 12$ billion fine. Although these Guidelines also provide that fines calculated this way are subject to the 10 percent cap, these figures nevertheless help to reinforce the conclusion that a fine much larger than $\$ 1.45$ billion could and should have been imposed.

${ }^{4} I d$. Their Microprocessor profit was approximately $\$ 56$ billion, but this includes profits and losses from products other than X86 chips.

5 See John M. Conner \& Robert H. Lande, How High Do Cartels Raise Prices? Implications for Optimal Cartel Fines, 80 TULANE L. REV. 513 (2005). ). See http://papers.ssrn.com/sol3/papers.cfm?abstract_id=787907. 
Intel's worldwide share of the chip market has fluctuated between 70 percent and 90 percent, and the prospects of new entry into this market are virtually nonexistent. In the United States this level of market dominance long has been considered that of a monopolist. Is it so surprising that a firm with a protected monopoly market share would price like a-well, like a monopolist? AMD recently estimated these overcharges have totaled $\$ 60$ billion since 1996. Regardless whether this precise figure is accurate, how many monopolies in history have used their power to set prices that were no higher than the competitive level? Can Intel really expect us to assume they enjoy a protected monopoly, yet showed this remarkable restraint? For all these reasons the EC's \$1.45 billion fine surely left Intel with a staggering reward from its illegal conduct.

\section{CONCLUSION: THIS IS WORLD WAR 4.0.}

Many called the highly publicized antitrust actions of the 1990s and early 2000s against Microsoft, by the United States and the Europeans, involving PC operating systems and related markets, World War 3.0. Now much of the world is engaged in a series of antitrust investigations and lawsuits against Intel that are just as important. These cases should result in headlines and capture the public attention the same way the Microsoft cases did a decade ago.

Although nothing in the EU is final, the Commission's findings against Intel are remarkably similar to those proven against Microsoft. Together, Microsoft and Intel monopolize the two key products that comprise PCs, and commonly are referred to as "the Wintel monopoly." Microsoft's share of the PC operating system market long has exceeded 80 percent, while Intel has at least this share of the market for the X86 chips used to power PCs worldwide. Only Intel and AMD have any chance of being a major player in the global $\$ 33$ billion X86 chip market for the foreseeable future.

Both involved a legally established monopolist trying to preserve its position through the use of illegal tactics. In neither case was the monopolist even accused of attempting to do this through excessive innovation, competition on the merits, or new product introduction. Rather, in both cases the disputed tactics focused on artificial impediments imposed against competitors-leveraging a monopoly against potential rivals through anticompetitive tactics, disguising predatory pricing, and taking steps specifically designed to suppress rivals.

During World War 3.0 Microsoft was found guilty of illegally maintaining its OS monopoly by a variety of anticompetitive tactics. For example, Microsoft took steps to prevent its browser rivals from distributing their products. Microsoft could establish no business justification for this or for the other tactics they deployed to destroy their main browser rival, Netscape. Similarly, Intel engaged in a variety of abusive practices to preserve its chip monopoly. As noted above, Intel 
provided substantial rebates to a leading PC retailer conditioned on the retailer only selling Intel-based PCs, and also provided substantial sham rebates to computer manufacturers "conditional on it obtaining all of its laptop CPU requirements from Intel." The sham discounts or rebates served no purpose other than to exclude Intel's main competitor. And there's more: "Intel made payments in order to induce" a leading computer manufacturer "to delay the planned launch of a product line incorporating an AMD-based CPU." These actions are opposite of traditional competition on the merits.

The Bush Administration's Department of Justice famously caved during their Microsoft case's remedy stage. Today, many years later, Microsoft still has a monopoly in the PC operating systems market. In light of this sad history, PC users everywhere should insist that enforcers pursue the Intel cases vigorously, and this time impose a remedy tough enough to bring competition to this crucial market.

Chips are sold in a worldwide market, so the European remedy almost certainly will have beneficial effects on chip sales in the United States. Moreover, this remedy is likely to cause lower prices that will especially benefit people outside the industrialized world, where there are vast numbers of people-including one billion children-for whom a computer is a luxury beyond reach. With more competition in the microprocessor market, people with the most pressing needs for communications and computing power will more easily be able to afford to connect to the global village.

We need to remember that this really is a World War. Tens of millions of computer users, from your grandmother to tomorrow's college students in the developing world, will be affected by its outcome. The $\$ 1.45$ billion fine was the equivalent of a parking ticket and will not seriously affect Intel's behavior. However, the Commission also ordered Intel to cease its illegal practices, and stated that it will "actively monitor Intel's compliance with this decision." Let's hope the European Commission learns from the U.S. Department of Justice's bungling of its Microsoft decree and sticks with the issues until consumers are victorious in World War 4.0. 